\title{
Nonel approaches to correction of mitochondrial dysfunction and oxidative disorders in Parkinson's disease
}

\author{
O. Gonchar ${ }^{1}$, I. Mankovska ${ }^{1}$, K. Rozova ${ }^{1}$, L. Bratus ${ }^{1}$, I. Karaban ${ }^{2}$ \\ ${ }^{1}$ O.O.Bogomoletz Institute of Physiology National Academy of Sciences of Ukraine, Kyiv; \\ ${ }^{2}$ D.F. Chebotarev Institute of Gerontology National Academy of Medical Sciences of Ukraine, Kyiv
}

\begin{abstract}
Mitochondrial dysfunction has been widely implicated in the neuronal degeneration in Parkinson's disease $(P D)$. The uses of mitochondria-targeted protective compounds that prevent or minimize a wide range of mitochondrial defects constitute potential therapeutic strategies in the prevention and treatment of neuronal degeneration in PD. This review discusses the latest findings in this field obtained in PD patients and animal and cellular models of PD with focusing on the effects of pharmacological agents on mitochondrial biogenesis, fission, fusion, mitophagy machinery, and transcription of endogenous cytoprotective antioxidant enzymes. We have also presented the data concerning the technologies for research and screening novel bioactive molecules to target mitochondrial dysfunction in Parkinson's disease.

Key words: Parkinson's disease, mitochondrial dysfunction, mitochondria-targeted protective compounds.
\end{abstract}

Parkinson's disease (PD) is a progressive agerelated neurodegenerative disease characterized clinically by presenting "TRAP” signs (tremor, rigidity, akinesia and postural instability) [1]. The pathological hallmarks of PD include preferential loss of dopaminergic (DA) neurons in the substantia nigra pars compacta $\left(\mathrm{SN}_{\mathrm{pc}}\right)$ of the brain and $\alpha$-synuclein containing inclusions (the so-called Lewy bodies) in neurons throughout the brain [2]. It is now firmly established that dysfunctional mitochondria and oxidative stress are crucial in PD pathogenesis [3, 4]. The first evidence linking mitochondrial dysfunction to the PD pathogenesis was the finding of the selective inhibition of mitochondrial complex I (a component of electron transport chain) along with the parkinsonism development in humans under accidental exposure to 1-methyl-4-phenyl1,2,3,6-tetrahydropyridine (MPTP) [5]. The other toxic inhibitors of complex I (rotenone, pyridaben, trichloroethylene and fenpyroximate) also induced the loss of nigrostriatal DA neurons [4]. The altered mitochondrial respiration has been shown to increase the production (C) O. Gonchar, I. Mankovska, K. Rozova, L. Bratus, I. Karaban of reactive oxygen species (ROS) in the mitochondria leading to neurodegeneration in PD [6]. Elevation of the established markers of oxidative stress has been demonstrated in brain tissue under the most prevalent neurodegenerative diseases, including PD [79]. The brain is most vulnerable to oxidative damage due to its high oxygen consumption, increased level of polyunsaturated fatty acids and redox-capable transition metal ions coupled with a relatively low level of antioxidants $[10,11]$. So, pharmacological agents targeting mitochondrial dysfunction and oxidative stress are prime candidates for neuroprotection in PD.

Mitochondrial dysfunction constitute potential therapeutic strategies in the prevention and treatment of these central nervous system diseases.

\section{Mitochondrial dysfunction: pharmacological} strategies for its ameliorating in PD

In general, mitochondrial dysfunction can be divided into two types: primary and secondary [12]. The primary type is connected with a 
mutation in mtDNA or in nuclear genes encoding mitochondrial proteins. Studies of mtDNA point mutations, typically heteroplasmic, in PD are extremely limited and their role in the development of mitochondrial dysfunction is difficult to interpret $[2,13]$. A number of studies concerning mutations to nuclear genes encoding mitochondrial proteins and leading to a wide range of mitochondrial defects in PD have been now presented [14]. The detailed analysis of these studies is beyond the scope of this review. But genetic studies have shown that certain autosomal-recessively inherited forms of PD can be caused by loss-of-function mutations in genes coding for mitochondrial proteins (i.e., PINK1 and DJ-1) involved in antioxidant protection [15, 16]. Moreover, several proteins that are associated with familial PD, including PTEN-induced putative kinase 1 (PINK1), DJ1, alpha-synuclein, leucine-rich repeat kinase 2 $\left(\right.$ LRRK $\left._{2}\right)$, and possibly Parkin, are either mitochondrial proteins or are associated with mitochondria, and all interlace with the pathways of oxidative stress and free radical damage, thus reinforcing the relevance of oxidative stress and mitochondrial dysfunction in the pathogenesis of the disease [17].

The clinical prospect of effective gene therapies for the primary mitochondrial disorders in PD remains distant. At the same time, secondary mitochondrial dysfunction caused by the events that originate outside mitochondria is a promising therapeutic target [12]. Parkinson's disease is the example of neurodegenerative illness having common patterns of cell disruption due to both primary and secondary mitochondrial dysfunction [18]. It was noted that mitochondrial dysfunction is emerging as a common feature suggesting a great pathogenic overlap among the familial, environmental and even sporadic forms of $\mathrm{PD}$ with a potential convergence at the level of mitochondrial quality control $[19,20]$.

So, pharmacological intervention can be useful to treat PD patients with primary and secondary mitochondrial disorders $[20,21]$.

The spectrum of mitochondrial disorders in
PD is very wide, it includes the respiratory chain dysfunction (inhibition of NADH-oxidation), hyperproduction of ROS in mitochondria, nitrosative stress development, an increase in the lipid peroxidation and protein oxidation levels in mitochondria, disruption to ATP synthesis, calcium dyshomeostasis, the mitochondrial permeability transition pore (mPTP) opening, the mitochondrial dynamic perturbation, and the mitochondrial clearance dysregulation $[6,18$, $22,23]$. These disorders were demonstrated in brain, skeletal muscle, lymphocytes and platelets of PD patients and in toxic and genetic experimental models of PD [17, 24-26].

There are at least three general pharmacological strategies for ameliorating of mitochondrial dysfunction [12]:1) targeting bioactive molecules to mitochondria; 2) modulating druggable mitochondrial targets and processes, and 3 ) affecting mitochondria indirectly by pharmacological agents acting on the transcription of mitochondrial genes.

\section{Mitochondria-targeted drugs in PD}

The first (delivery) strategy pivots primarily around the direction of bioactive molecules to mitochondria [27]. There was first demonstration the use of lipophilic cations to facilitate the delivery of attached mitochondria-targeted drugs within cells [28]. Since then, lipophilic cations such as triphenyl-phosphonium (TPP) as well as the Szeto-Schiller (SS) peptides and the mitochondria-penetrating peptides $\left(\mathrm{MPP}_{\mathrm{s}}\right)$ were used to direct small molecules to mitochondria [29, 30]. In particular, SS31 and SS20 are novel peptide antioxidants targeted to the inner mitochondrial membrane and protected neurons in MPTP model of PD: they decrease mitochondrial ROS production, inhibit the mPTP opening and mitochondrial swelling, reduce cytochrome c release, prevent apoptosis and necrosis [27]. The mitochondria-targeting strategies were recently expanded owing to extensive work on mitochondria-targeted TPP compounds [12]. In particular, the mitochondriatargeted antioxidant MitoQ (the TPP-modified 
ubiquinone) has shown efficacy in the animal models and human studies of PD [31, 32]. It was shown that MitoQ inhibits mitochondrial lipid peroxidation and reacts directly with oxidants such as peroxynitrite. The other TPP-modified antioxidants (targeted versions of nitroxide, nitrones, plastoquinons and tocopherol) have also shown to be effective in animal models of PD [33].

In our opinion, the distinction between second and third strategies for mitochondrial pharmacology are quite conditional because mitochondria form a complex reticulum with other cell organelles and this complex is highly dynamic [34]. The modern approaches to develop mitochondrial pharmacology for $\mathrm{PD}$ are to modulate different pathways that are involved in pathogenesis of mitochondrial dysfunction and oxidative stress [18].

\section{Untargeted mitochondrial antioxidants in PD}

Oxidative damage to proteins, lipids and DNA and reduced levels of GSH, a major antioxidant in cells, provide compelling reasons for an antioxidant approach to the treatment of PD. The hormone melatonin has been shown to exert in vivo mitochondrial protective action in MPTP-induced mice model, 6-OHDA- and rotenone-induced rat models by maintaining mitochondrial membrane potential, increasing antioxidant enzymates activity (i.e., SOD, CAT) and the content of nonenzymatic compounds (i.e., glutathione), inhibiting ROS overproduction, increasing ATP production, decreasing calcium concentration levels, and enhancing mitochondrial complex I activity $[35,36]$. Several natural products from medicinal plants, both isolated compounds and extracts, have been demonstrated in in vitro and in vivo studies to exert promising mitochondrial protection. As extracts, it has been reported that berries rich in anthocyanidins and proanthocyanidins protect mitochondria from rotenone-induced changes in the respiratory chain [37]. The silymarin, which is a standardized extract of the milk thistle seeds, sustained mitochondrial integrity and function and inhibited mitochondrial apoptotic pathway in $\mathrm{MPP}(+)$-induced rat model [38]. Green tea polyphenols have been also evidenced to inhibit mitochondrial apoptotic pathway (increasing $\mathrm{Bcl} 2$ and decreasing caspase- 3 activity) and to preserve mitochondrial membrane potential, to inhibit ROS production and calcium concentration levels [39]. The licorice (root of Glycyrrhiza glabra) inhibited dopaminergic apoptotic cell death as evidenced in the increase in Bcl2 levels and in the decrease in Bax levels, caspase-3 activity, cytochrome c release, and c-Jun N-terminal kinase (JNK) and mitogenactivated protein kinase (MAPK) activities in a model of 6-OHDA-induced Parkinson's disease [40]. The herbal medicine Chunghyuldan inhibited caspase-3, ROS generation and retained mitochondrial membrane potential in 6-OHDA Parkinson's disease model [41]. The polyphenol hesperidin inhibited mitochondrial apoptotic pathway (increased Bc12 levels, decreased Bax, caspase- 3 and caspase- 9 activities and inhibited cytochrome c release), supported mitochondrial membrane potential, inhibited ROS production, and increased glutathione levels in in vitro human neuroblastoma SK-N-SH cells and in rat model of rotenone-induced parkinsonism [42]. Quercetin rescued toxic-induced defects in mitochondria in in vitro and in vivo experiments. Quercetin inhibited ROS generation and maintained mitochondrial membrane potential in rotenone-induced rat model of PD [43]. Moreover, quercetin decreased the production of superoxide radicals and inhibited the expression of the inducible nitric oxide synthase protein expression in in vitro glial-neuronal system model of MPP $(+)$-induced Parkinson's disease [44]. The flavonoid baicalein inhibited in vitro apoptotic mitochondrial cell death and saved mitochondrial integrity and function in both SHSYTY and PC12 cells in 6-OHDA and rotenone Parkinson's disease models as evidenced in the decrease in caspase-3, caspase-7, caspase- 9 and JNK activities and in the maintenance of mitochondrial membrane potential, increment of ATP content and reduction of ROS production 
[45-47]. The polyphenol curcumin derived from the spice turmeric acts as mitochondrial antiapoptotic agent through the inhibition of caspase- 3 and caspase- 9 activities and cytochrome c release and it also protects mitochondrial integrity and function via ROS production inhibition and complex I activity enhancement [48]. Other natural products with mitochondrial protective effect are the coumarins umbelliferone, esculetin and osthole which in in vitro and in vivo Parkinson's disease models have been demonstrated to possess antiapoptotic properties on mitochondria $[49,50]$. The carotenoid lycopene inhibited macromolecular mitochondrial damage (lipids, DNA and proteins), overproduction of ROS, ATP failed production, and cytochrome c release in $\mathrm{MPP}(+)$-induced human neuroblastoma SK-N-SH cells and rotenone-induced rat model of PD [51, 52].

A number of compounds have been proposed to reduce oxidative stress and prevent dopaminergic cell death in toxic models of PD. They scavenged oxygen free radicals, inhibited iron accumulation, prohibited the peroxidation of membrane lipids, participated in a wide range of redox reactions and decreased the accumulation of oxidized proteins in the SNpc. Antioxidative and neuroprotective properties of these compounds (vitamins, stimulants, supplements and other drugs) have been reported (for review, see [53]). This review also identifies Rasagline, Minocycline and creatine as the most promising neuroprotective agents for PD patients targeting oxidative stress and mitochondrial dysfunction.

We can consider recent promising investigations of $\mathrm{NAD}^{+}$-precursors as pharmacological agents to correct the original metabolic defect. The using of $\mathrm{NAD}^{+}$-precursors could be beneficial for the PD therapy in the future correcting a decrease in the $\mathrm{NAD}^{+} / \mathrm{NADH}$ ratio, increasing mitochondrial biogenesis, and reducing mtDNA deletion accumulation [54]. Modulating pathways that are involved in transcription of the antioxidant enzymes in PD

Although oxidative stress has been implicated in the pathogenesis of several neurodegen- erative diseases, therapies based on exogenous antioxidants have been disappointing [55]. High levels of antioxidants are needed to achieve protective effects in the CNS, as most exogenous antioxidants do not efficiently cross the bloodbrain barrier owing to their hydrophilic nature. Furthermore, administration of antioxidants is limited because of their toxicity at high doses, resulting in a small therapeutic window of these agents [55]. This emphasizes the need for alternative strategies to therapeutically counteract the detrimental effects of ROS and restore the cellular redox balance. A promising possibility to limit ROS-mediated damage is the activation of endogenous antioxidant enzymes present in the CNS, such as catalase, superoxide dismutase, and peroxiredoxins [56]. Transcription of these cytoprotective proteins is under control of the nuclear transcription factor NF-E2-related factor 2 (Nrf2), which plays a central role in the regulation of the cellular redox status [57]. Modulating pathways that are involved in transcription of the antioxidant enzymes is the approach to develop therapeutic strategies for PD. The Nrf2/ ARE pathway is one such pathway. Expression of most antioxidant enzymes is tightly controlled by the antioxidant response element (ARE) and nuclear factor Nrf2 which is a major regulator of the cellular response to oxidative stress by induction of antioxidant and detoxification enzymes and proteins such as glutathione-S-transferase, NAD $(\mathrm{P}) \mathrm{H}$ : quinoneoxidoreductase-1, superoxide dismutase, glutathione peroxidase, heme oxygenase-1, glutamate cysteine ligase, thioredoxin and catalase [58-60]. The ability of the Nrf2/ARE pathway to regulate genes associated with antioxidant defense, autophagy and proteasome activation has been attracting attention to the use of Nrf2 activators as therapeutic strategies for neurodegenerative diseases. Small food-derived inducers of the Nrf2/ARE pathway including 1-sulforaphane from broccoli and isoliquiritigenin from licorice displayed promising protection of mitochondrial function in models of oxidative stress and neurodegenerative diseases and represent a novel approach to 
prevent and treat aging-associated neurodegenerative diseases [61, 62].

Several constituents of vegetables such as 1sulforaphane (SFN) from broccoli or ingredients of spices such as S-allyl-1-cysteine (SAC) from garlic are known to activate the transcription factor Nrf2. A variety of these natural Nrf2 activators have proven efficiency in both in vitro and in vivo models of neurological disorders $[59,62]$. These activators (such as triterpenoids) were shown to offer neuroprotection against MPTP-induced toxicity [63]. Synthetic triterpenoids (TP) inhibit oxidative stress and cellular inflammatory processes by potently activating the antioxidant response element (ARE)-Nrf2Keap1 signaling pathway. Activation of Nrf2 by TP leads to dissociation of Nrf2 from Keap1, translocation to the nucleus and binding to the ARE promoter sequences. Such binding results in coordinated induction of a battery of cytoprotective genes, including antioxidant and antiinflammatory genes. It has been proposed that the new activator of the Nrf2 pathway dimethylfumarate (DMF) may be used for the treatment of not only multiple sclerosis but PD, too [64]. It was recently shown that monomethylfumarate which is a bioactive metabolite of DMF acts as a neuroprotector in the MPTP model of PD [65].

So, the activation of the Nrf2/ARE signaling pathway might represent a therapeutic target for the treatment of PD. Remarkably, only limited studies have been performed with these inducers, emphasizing the need for future experiments. Hence, additional studies are essential to further unravel the functional role of these inducers in different animal models of neurodegeneration. However, further studies are required to obtain more insights into the molecular mechanisms of Nrf2 activation and clinical application of these small compounds.

\section{Drugs acting on mitochondrial biogenesis and dynamics in PD}

The novel strategy for mitochondrial pharmacology is related with using small molecules to modulate systems outside mitochondria that control the number and activity of the organelles. Such modulation can be achieved by altering the transcription of nuclear-encoded mitochondrial proteins that control the major mitochondrial pathways regulating mitochondrial biogenesis, fission, fusion and mitophagy [66]. Mitochondrial dynamics includes processes of fission and fusion, mitophagy and movement with varying degrees of speed within cells $[67,68]$. Fission and fusion are highly regulated and controlled by GTPases: with dynamin-related protein1 (Drp1) driving fission and the collaboration of mitofusions 1 and 2 (Mfn1 and Mfn2) with Opa 1 facilitating fusion. Perturbations in mitochondrial dynamics and activity are directly or indirectly involved in neurodegenerative diseases [68, 69]. In general, fusion is a pro-survival mechanism protecting against apoptosis and neurodegeneration whereas mitochondria undergoing fission are prone to disposal [70]. There are now a limited number of compounds that specifically regulate mitochondrial fission and fusion: Mdivi-1 (mitochondrial division inhibitor) that inhibits Drp1, and 15-oxospiramilactone (S3) that inhibits USP30, a mitochondrially localized deubiquitinase, and hydrazine (M1) with an unknown target $[71,72]$. These small molecules may represent useful starting points for drugs that are pro-fusion, i.e., they either block fission (Mdivi-1) or enhance fusion (M1, S3) [54]. Recently, inhibition of Drp1 has been tested in two PD models: genetic (aPINK 1//-mouse) and toxic (the MPTP mouse model) [73]. The authors demonstrated that: 1) Drp1 inhibition attenuates neurotoxicity and dopamine release deficits in vivo, and 2) pushing the balance of fission-fusion toward fusion is beneficial in PD models with altered mitochondrial function. Furthermore, Drp1 has also been shown to interacted with a PD-related protein $\mathrm{LRRK}_{2}$ [71]. This interaction enhances mitochondrial translocation of Drp 1 to promote mitochondrial fragmentation with increased vulnerability of DA neurons to oxidative stress and impaired mitochondrial and cellular health. It was recent- 
ly established that one of the most promising therapeutic targets for potential treatment of PD is $\mathrm{LRRK}_{2}$ (for review, see [74]). This review summarized several published studies showing the feasibility of developing potent, selective and brain permeable LRRK $_{2}$ kinase inhibitors applicable for PD therapy.

It is widely known that PGC1- $\alpha$ is the key transcriptional co-activator protein that upregulates the activity of other transcription factors involved in mitochondrial biogenesis, such as NRF-1 and transcription factor A (TFAM) [75]. The level of PGC1 - $\alpha$ expression is controlled by the activity of peroxisome proliferator-activated receptor $\left(\mathrm{PPAR}_{\gamma}\right)$, the activity of AMP-activated kinase (AMPK) acting as a cytosolic ATP/ADP sensor, and the activity of $\mathrm{NAD}^{+}$-dependent deacetylase Sirt 1, a member of sirtuin family. It was established that in mice treated with MPTP to induce Parkinson's-like phenotypes, PGC1- $\alpha$ overexpression through the neuronalspecific thy-1 promoter significantly protected dopaminergic neurons from MPTP-induced degeneration [76]. Helliwell, 2016 discussed multiple routes to $\mathrm{PGC} 1-\alpha$ activation using the low-molecular weight compounds that target Sirt 1 and/or AMPK and PPAR [54]. In particular, resveratrol (a natural stilbenoid found in the skin of grapes) was initially proposed as an activator of Sirt 1 [77]. Resveratrol has been tested in mouse model of PD [76]. where PGC1- $\alpha$ is a likely efficacy target. A recent study showed that necdin which stabilizes PGC- $1 \alpha$ protects against neurotoxicity induced by MPTP [78]. Thus, the pharmacological manipulation of PGC1- $\alpha$ activity through the use of the PPAR and AMPK agonists (Bezafibrate and AICAR, respectively) is a promising strategy as a "mitochondrial therapy" for PD but significant assessment of mitochondrial function in the animal models and clinical trials is still lacking [54].

\section{Drugs acting on mitochondrial quality control in PD}

It is known that cells have developed a mechanism to eliminate dysfunctional mitochondria via mitophagy which is a type of selective mitochondria-specific autophagy. Different mitophagy pathways have been established in the last decades but the PINK 1/Parkindependent mytophagy (an ubiquitin-dependent process) has been predominantly implicated in pathogenesis of PD [79]. Upon loss of the mitochondrial membrane potential, PINK 1 (a serine/threonine kinase) accumulates at the mitochondrial membrane where its activity recruits Parkin (an E3 ubiquitin ligase) from the cytosol to the depolarized mitochondria. Then, Parkin ubiquitinates several mitochondrial membrane proteins creating a signal for the removal of damaged mitochondria. Mutations in the genes encoding PINK1 and Parkin are responsible for the autosomal - recessive cases of PD which display an accumulation of damaged mitochondria in the SNpc [80, 81]. It was shown that in Parkin-deficient mice mitochondrial dysfunction and oxidative damage were registered within the SNpc [82]. PINK 1 deficiency also leads to mitochondrial dysfunction [83]. The $3^{\text {rd }}$ gene which is associated with $\mathrm{PD}$ is $D J-1$; the loss of $\mathrm{DJ}-1$ results also in mitochondrial dysfunction, this protein appears to act in the same PINK 1/Parkindependent manner [81]. Interestingly, DJ-1 takes part in the oxidative stress response and has a role in neuroprotection due to cysteine-sulfinic acid-driven mitochondrial localization [84]. It is important that the loss of DJ-1 can be rescued by Parkin overexpression [85]. In general, overexpression of mitophagy proteins such as Parkin (in animal models of PD) has beneficial effect preventing neuronal decline [86]. So, a novel concept for the treatment of mitochondrial disorders by targeting regulatory components of the mitophagy machinery and upregulating this pathway is regarded now as valuable for PD therapy $[79,87,88]$.

There are a number of compounds that increase Parkin function in vitro, including epigenetic agents, cholesterol synthesis modulators, and JNK inhibitors [89]. In particular, it has been found that small molecule JNK inhibitors 
protect dopaminergic neurons in MPTP model of PD [90]. The activation of a PINK 1 neosubstrate (PINK 1 yielded kinetin triphosphate) by the kinetin triphosphate precursor (kinetin) administration was able to increase the catalytic activity of PINK 1 directing Parkin to depolarized mitochondria in cellular models of PD [91]. It is known that Parkin's enzymatic functions are antagonized by de-ubiquitylation enzymes (DUBs) [92]. First small molecule DUB inhibitors as well as Parkin activators are already under development and could furnish the next generation drugs for disease-modifying therapies [20].

In our recent study, we have found that the use of the new compound Capicor (Meldonium connected with $\gamma$-butyrobetain) in the PD patients therapy results in overexpression of Parkin in leukocytes, normalization of prooxidantantioxidant balance in blood plasma, prevention of mitochondrial degradation, stimulation of mitochondrial fusion and elimination of damaged mitochondria in platelets via the mitophagy pathway [93]. Presumably, this compound can act through DJ-1-related pathway which works in parallel with PINK1/Parkin [85]. We have shown (unpublished data) that the use of Capicor increased $D J-1$ expression in rat brain and heart tissues in rotenone-induced Parkinson's-like syndrome.

As it has shown in rotenone- and MPTPtreated mice phenylbutyrate increased $D J-1$ expression that protected DA neurons in $\mathrm{SNpc}$ and reduced deterioration in motor and cognitive functions [94, 95].

\section{Technologies for screening bioactive molecules to target mitochondrial dysfunction in PD}

Promising technologies have been the used for research and screening novel bioactive molecules to target mitochondrial dysfunction in PD: patient-derived cybrids [96] and induced Pluripotents stem cells (iPSC s $_{\text {) }}$ [97, 98]. In these two studies, the neural-like cells from $\mathrm{iPSC}_{\mathrm{s}}$ carrying PD-causative PINK 1 or $L R R K_{2}$ mutations were investigated. It was shown pharmacological (coenzyme $\mathrm{Q}_{10}$ and rapamycin) rescue of associated mitochondrial dysfunction [97]. Beside that, neurons carrying $L R R K_{2}$ mutation were corrected to wild type using $\mathrm{Zn}$ finger nucleases [98]. The mammalian target of rapamycin (mTOR) inhibition (by rapamycin) could be beneficial in patients with PD so long as mTOR is a negative regulator of autophagy and mitophagy [54].

In addition, the use of the new compounds restoring mitochondrial functions in cell culture models such as iPSC-derived dopaminergic neurons (the orphan nuclear receptors Nurr1 activators, the retromer pathway activators, etc) also represents a modern pharmacological approach for the development of novel neuroprotective strategies for PD [18, 99, 100]. It was shown that Nurr1 activating compounds not only improve DA neurotransmission but also protect DA neurons from environmental toxins or neuroinflammation mediated by microglia [100].

In the search of alternative methods of treatment and diagnosis, contemporary science is increasingly reaching for tools in the field of nanomedicine, for example, fullerenes and their water-soluble derivatives. Due to their hydrophilic properties and the ability to scavenge free radicals, fullerenols may, in the future, provide a serious alternative to the currently used pharmacological agents in chemotherapy, treatment of neurodegenerative diseases, and radiobiology. Water-soluble derivatives of fullerenes (fullerenols and malonic acid derivatives) scavenge ROS more efficiently than conventional antioxidants [101-106]. Therefore, hydrophilic fullerene derivatives are promising candidates for the use as neuroprotective and antioxidant agents, as confirmed in electrophysiological studies indicating that two fullerene derivatives $(\mathrm{C} 60(\mathrm{OH}) 12$ and $\mathrm{C} 60(\mathrm{OH}) 18-2003-7)$ showed excellent antioxidant properties (confirmed by electron paramagnetic resonance). These fullerene derivatives decreased excitotoxicity, induced neuronal death of mouse neocortical neurons up to $80 \%$ and were antiapoptotic. Similar results were obtained by Jin et al., 2000, who demonstrated that fullerenols exerted a neu- 
roprotective effect on neuronal cultures in vitro by blocking glutamate receptors and reducing the concentration of intracellular calcium [102]. It is interesting to note that the carboxyl derivative of C60 effectively protected dopaminergic neurons against the harmful effects of oxidative stress caused by neurotoxins [101]. Interestingly, fullerenol turned out to be an effective neuroprotector in a cellular model of PD. Cai et al., 2008 reported that fullerenol $\mathrm{C} 60(\mathrm{OH}) 24$ effectively scavenged free radicals, suggesting that it may be a potential neuroprotective agent against mitochondrial dysfunction induced by MPP+ [104]. Other authors confirmed that fullerenes might accumulate in mitochondria [103]. Despite the convincing evidence concerning the neuroprotective properties of water-soluble fullerene derivatives, little is known about their mechanism of action and possible side effects occurring in the neural tissue. Therefore, the potential therapeutic properties of fullerenols in the treatment of neurologic diseases, including $\mathrm{PD}$, require further investigation.

\section{Perspectives}

Schapira et al., 2014 proposed several target pathways in PD that merit further study [21]. These targets include agents that might improve mitochondrial function or increase degradation of defective mitochondria, kinase inhibitors, calcium channel blockers, and approaches that interfere with the misfolding, templating, and transmission of $\alpha$-synuclein. In our review, we try to focus on the promising pharmacological interventions which modulate different pathways involved in development of mitochondrial dysfunction and oxidative stress in PD. Such pathways have been implicated in mitochondrial dynamics and clearance dysregulation, in particular, mitochondrial biogenesis, fission, fusion, and the mitophagy machinery as well as in molecular mechanisms of antioxidant cell defense.

The authors of this study confirm that the research and publication of the results were not associated with any conflicts regarding commercial or financial relations, relations with organizations and/or individuals who may have been related to the study, and interrelations of coauthors of the article.

\section{О.А. Гончар, И.Н. Маньковская, Е.В. Розова, Л.В. Братусь, И.Н. Карабань \\ НОВЫЕ ПОДХОДЫ К КОРРЕКЦИИ МИТОХОНДРИАЛЬНОЙ ДИСФУНКЦИИ И ОКСИДАТИВНОГО СТРЕССА ПРИ БОЛЕЗНИ ПАРКИНСОНА}

Митохондриальная дисфункция и оксидативный стресс являются центральными звеньями патогенеза болезни Паркинсона (БП). Фармакологическая коррекция этого заболевания включает предотвращение или минимизацию широкого спектра проявлений митохондриальных дефектов: гиперпродукцию активных форм кислорода, нарушения в системе митохондриального электронного транспорта и синтеза АТФ, дисрегуляцию митохондриальной динамики и клиренса. В представленном обзоре обсуждаются новейшие исследования в области митохондриальной фармакологии (в том числе и собственные), выполненные на животных и клеточных моделях БП и полученные у больных. Обзор фокусирован на влиянии фармакологических агентов на митохондриальный биогенез, процессы слияния и разделения митохондрий и траскрипцию цитопротективных антиоксидантных ферментов.

Ключевы слова: болезнь Паркинсона; митохондриальная дисфункция; митохондриальнонаправленные протекторные соединения.

\section{О.О. Гончар ${ }^{1}$, І.М. Маньковська ${ }^{1}$, К.В. Розова ${ }^{1}$, Л.В. Братусь ${ }^{1}$, І.М. Карабань ${ }^{2}$ \\ НОВІ ПІДХОДИ ДО КОРЕКЦІї МІТОХОНДРІАЛЬНОї ДИСФУНКЦІї ТА ОКСИДАТИВНОГО СТРЕСУ ПРИ ХВОРОБІ ПАРКІНСОНА}

Мітохондріальна дисфункція та оксидативний стрес $є$ центральними ланками патогенезу хвороби Паркінсона (ХП). Фармакологічна корекція цього захворювання включає попередження чи мінімізацію широкого спектра проявів мітохондріальних дефектів: гіперпродукцію активних форм кисню, порушень в системі мітохондріального електронного транспорту та синтезу АТФ, дисрегуляцію мітохондріальної динаміки та кліренса. У огляді обговорюються нові дослідження в галузі мітохондріальної фармакології (у тому числі і власні), проведені на тваринних і клітинних моделях ХП, а також одержані у хворих. Огляд фокусується на впливі фармакологічних агентів на мітохондріальний біогенез, процеси з"єднання і ро- 
зділення мітохондрій та транскрипцію цитопротективних антиоксидантних ферментів.

Ключові слова: хвороба Паркінсона; мітохондріальна дисфункція; мітохондріальнонацілені протекторні сполуки.

${ }^{1}$ Інститут фізіології ім. О.О.Богомольия НАН України; ${ }^{2}$ Інститут геронтології ім. Д.Ф. Чеботарьова НАМН Украӥни, Київ

\section{REFERENCES}

1. Frank C, Pari G, Rossiter JP. Approach to diagnosis of Parkinson disease. Can Fam Physician. 2006;52: 862-8.

2. Hudson G. The ageing brain, mitochondria and neurodegeneration. In: Reeve AK, Simcox EM, Duchen MR, Turnbull DM, eds. Mitochondrial Dysfunction in Neurodegenerative Disorders. $2^{\text {nd }}$ ed. Springer Int Publishing 2016;59-80.

3. Beal MF. Mitochondria take center stage in aging and neurodegeneration. Ann Neurol. 2005;58:495-505.

4. Chaturvedi RK and Beal M. Mitochondrial approaches for neuroprotection. Ann NY Acad Sci. 2008;1147:395-412.

5. Langston JW, Ballard P, Tetrud JW and Irwin I. Chronic Parkinsonism in humans due to a product of meperidineanalog synthesis. Science. 1983;219:979-80. -

6. Jenner P. Oxidative stress in Parkinson's disease. Ann Neurol. 2003; 53 (suppl 3):S26-36 doi:10.1002/ana.10483

7. Lin MT and Beal MF. Mitochondrial dysfunction and oxidative stress in neurodegenerative diseases. Nature. 2006;443:787-95.

8. Pan-Montojo F, Schwarz M, Winkler C, Arnhold M, O’Sullivan GA, Pal A, Said J, Marsico G, Verbavatz JM, Rodrigo-Angulo M, Gille G, Funk RH, Reichmann H. Environmental toxins trigger PD-like progression via increased alpha-synuclein release from enteric neurons in mice. Sci Rep. 2012;2:898.

9. Majd S, Power JH, Grantham HJ. Neuronal response in Alzheimer's and Parkinson's disease: the effect of toxic proteins on intracellular pathways. BMC Neurosci. 2015;16:69.

10. Cannon JR, Greenamyre JT. Neurotoxic in vivo models of Parkinson's disease recent advances. Prog Brain Res. 2010;184:17-33.

11. Picard M, McManus MJ. Mitochondrial signaling and neurodegeneration. In: Reeve AK, Simcox EM, Duchen MR, Turnbull DM, eds. Mitochondrial Dysfunction in Neurodegenerative Disorders. $2^{\text {nd }}$ ed. Springer Int Publishing 2016;107-37.

12. Smith RAJ, Hartley RC, Cocheme HM, Murphy MP. Mitochondrial pharmacology. Trends Pharm Sci. 2012;33(6):341-52.

13. Hudson G, Nalls M, Evans JR, Breen DP, Winder-Rhodes $\mathrm{S}$, Morrison KE, Morris HR, Williams-Gray CH, Barker RA, Singleton AB, Hardy J, Wood NE, Burn DJ, Chinnery PF. Two-stage association study and meta-analysis of mitochondrial DNA variants in Parkinson's disease. Neurology. 2013;80:2042-48.
14. Leonard JV, Schapira AH. Mitochondrial respiratory chain disorders II: neurodegenerative disorders and nuclear gene defects. Lancet 2000;355:389-94.

15. Taira T, Saito Y, Niki T, Iguchi-Ariga SM, Takahashi K, Ariga H. DJ-1 has a role in antioxidative stress to prevent cell death. EMBO Rep. 2004;5:213-18.

16. Moore DJ, Zhang L, Troncoso J, Lee MK, Hattori N, Mizuno Y, Dawson TM, Dawson VL. Association of DJ-1 and parkin mediated by pathogenic DJ-1 mutations and oxidative stress. Hum Mol Genet. 2005;14:71-84.

17. Schapira AH. Mitochondria in the aetiology and pathogenesis of Parkinson's disease. Lancet Neurol. 2008;7:97-109.

18. Bose A and Beal MF. Mitochondrial dysfunction in Parkinson's disease. J Neurochem. 2016; 139(Suppl.1):216-31.

19. Ryan BJ, Hoek S, Fon EA, Wade-Martins R. Mitochondrial dysfunction and mitophagy in Parkinson's: From familial to sporadic disease. Trends Biochem Sci. 2015; 40:200-10.

20. Truban D, Hou X, Caulfield TR, Fiesel FC, Springer W. PINK 1, Parkin, and Mitochondrial Quality Control: What can we learn about Parkinson's disease pathobiology? J Parkinson's disease. 2017;7:13-29.

21. Schapira HV, Olanow CW, Greenamyre JT, Bezard E. Slowing of neurodegeneration in Parkinson's disease and Huntington's disease: future therapeutic perspectives. The Lancet. 2014;384:545-55.

22. Stewart VC, Heales SJ. Nitric oxide-induced mitochondrial dysfunction: Implications for neurodegeneration. Free Radic Biol Med. 2003; 34:287-303.

23. Henchcliffe $\mathrm{C}$ and Beal MF. Mitochondrial biology and oxidative stress in Parkinson's disease pathogenesis. Nature Clin Pract Neurol. 2008;4:600-09.

24. Narendra DP, Youle RJ. Targeting mitochondrial dysfunction: role for PINK1 and Parkin in mitochondrial quality control. Antioxid Redox Signal. 2011;14:1929-38.

25. Perier C, Bové J, Dehay B, Jackson-Lewis V, Rabinovitch PS, Przedborski S, and Vila M. Apoptosis-inducing factor deficiency sensitizes dopaminergic neurons to parkinsonian neurotoxins. Ann Neurol. 2010;68:184-92.

26. Franco-Iborra S, Vila M, Perier C. The Parkinson's disease mitochondrial hypothesis: where are we at? Neuroscientist 2016;22:266-77.

27. Milane L, Trivedi M, Singh A, Talekar M, Amiji M. Mitochondrial biology, targets, and drug delivery. J Control Release. 2015;207:40-58.

28. Teicher BA, Holden SA, Cathcart KN. Efficacy of $\mathrm{Pt}(\mathrm{Rh}-123) 2$ as a radiosensitizer with fractionated $\mathrm{X}$ rays. Int J Radiat Oncol Biol Phys. 1987;13:1217-24.

29. Szeto HH, Schiller PW. Novel therapies targeting inner mitochondrial membrane - from discovery to clinical development. Pharm Res. 2011; 28:2669-79.

30. Yousif LF, Stewart KM, Kelley SO. Targeting mitochondria with organelle-specific compounds: strategies and applications. Chem Biochem. 2009;10:1939-50.

31. Snow BJ, Rolfe FL, Lockhart MM, Frampton CM, O'Sullivan JD, Fung V, Smith RA, Murphy MP, Taylor KM. A double-blind, placebo-controlled study to 
assess the mitochondria-targeted antioxidant MitoQ as a disease-modifying therapy in Parkinson's disease. Mov Disord. 2010; 25:1670-74.

32. Smith RA and Murphy MP. Animal and human studies with the mitochondria-targeted antioxidant MitoQ. Ann NY Acad Sci. 2010;1201:96-103.

33. Ghosh A, Solesio ME, Prime TA, Logan A, Murphy MP. Neuroprotection by a mitochondria-targeted drug in a Parkinson's disease model. Free Radic Biol Med. 2010;49:1674-84.

34. Twig G, Shirihai O S. The interplay between mitochondrial dynamics and mitophagy. Antioxid Redox Signal. 2011;14:1939-51.

35. Patki G, Lau Y-S. Melatonin protects against neurobehavioral and mitochondrial deficits in a chronic mouse model of Parkinson's disease. Pharmacol Biochem Behavior. 2011;99(4):704-11.

36. Dabbeni-Sala F, di Santo S, Franceschini D, Skaper SD, and Giusti P. Melatonin protects against 6-OHDAinduced neurotoxicity in rats: a role for mitochondrial complex I activity. FASEB J. 2001;15(1):164-70.

37. Strathearn KE, Yousef GG, Grace MH, Roy SL, Tambe MA, Ferruzzi MG, Wu QL, Simon JE, Lila MA, Rochet JC. Neuroprotective effects of anthocyanin- and proanthocyanidin-rich extracts in cellular models of Parkinson's disease. Brain Res. 2014; 1555:60-77.

38. Geed M, Garabadu D, Ahmad A, and Krishnamurthy S. Silibinin pretreatment attenuates biochemical and behavioral changes induced by intrastriatal MPP+ injection in rats. Pharmacol Biochem Behavior. 2014;117:92-103.

39. Guo S, Bezard E, and Zhao B. Protective effect of green tea polyphenols on the SH-SY5Y cells against 6-OHDA induced apoptosis through ROS-NO pathway. Free Radic Biol Med. 2005;39(5):682-95.

40. Hwang CK, Chun HS. Isoliquiritigenin isolated from licorice Glycyrrhiza uralensis prevents 6-hydroxydopamine induced apoptosis in dopaminergic neuron. Biosci Biotechnol Biochem. 2012;76(3):536-43.

41. Kim HG, Ju MS, Kim DH, Hong J, Cho SH, Cho KH, Park W, Lee EH, Kim SY, Oh MS Protective effects of Chunghyuldan against ROS-mediated neuronal cell death in models of Parkinson's disease. Basic Clin Pharmacol Toxicol. 2010; 107 (6):958-64.

42. Tamilselvam K, Braidy N, Manivasagam T, Essa MM, Prasad NR, Karthikeyan S, Thenmozhi AJ, Selvaraju S, Guillemin GJ. Neuroprotective effects of hesperidin, a plant flavanone, on rotenone induced oxidative stress and apoptosis in a cellular model for Parkinson's disease. Oxid Med Cell Longev. 2013;2013:102741.

43. Karuppagounder SS, Madathil SK, Pandey M, Haobam R, Rajamma U, Mohanakumar KP. Quercetin up-regulates mitochondrial complex I activity to protect against programmed cell death in rotenone model of Parkinson's disease in rats. Neuroscience. 2013;236:136-48.

44. Bournival J, Plouffe M, Renaud J, Provencher C, Martinoli M-G. Quercetin and sesamin protect dopaminergic cells from MPP+-induced neuroinflammation in a microglial
(N9)-neuronal (PC12) coculture system. Oxid Med Cell Longev. 2012; 11.

45. Wang Y-H, Yu H-T, Pu X-P, Du G-H. Baicalein prevents 6-hydroxydopamine-induced mitochondrial dysfunction in SH-SY5Y cells via inhibition of mitochondrial oxidation and up-regulation of DJ-1 protein expression. Molecules. 2013 ;18(12):14726-38.

46. Li XX, He GR, Mu X, Xu B, Tian S, Yu X, Meng FR, Xuan ZH, Du GH. Protective effects of baicalein against rotenone-induced neurotoxicity in PC12 cells and isolated rat brain mitochondria. Eur J Pharmacol. 2012;674(23):227-33

47. Jagatha B, Mythri RB, Vali S, Bharath M. M. S. Curcumin treatment alleviates the effects of glutathione depletion in vitro and in vivo: therapeutic implications for Parkinson's disease explained via in silico studies. Free Radic Biol Med. 2008;44(5):907-17.

48. Liu Z, Yu Y, Li X, Ross CA, Smith WW. Curcumin protects against A53T alpha-synuclein-induced toxicity in a PC12 inducible cell model for Parkinsonism. Pharmacol Res. 2011;63(5):439-44.

49. Subramaniam SR and Ellis EM. Neuroprotective effects of umbelliferone and esculetin in a mouse model of Parkinson's disease. J Neurosci Res. 2013;91(3):453-61.

50. Liu WB, Zhou J, Qu Y, Li X, Lu CT, Xie KL, Sun XL, Fei $Z$. Neuroprotective effect of osthole on MPP+-induced cytotoxicity in PC12 cells via inhibition of mitochondrial dysfunction and ROS production. Neurochem Int. 2010;57(3):206-15.

51. Yi F, He X, Wang D. Lycopene protects against MPP+-induced cytotoxicity by maintaining mitochondrial function in SH-SY5Y cells. Neurochem Res. 2013;38(8):1747-57.

52. Kaur H, Chauhan S, Sandhir R. Protective effect of lycopene on oxidative stress and cognitive decline in rotenone induced model of Parkinson's disease. Neurochemic Res. $2011 ; 36(8): 1435-43$.

53. Seidl SE and Potashkin JA. The promise of neuroprotective agents in Parkinson's disease.Front Neurol; 2011; 2: 68.

54. Helliwell SB.. Development of treatments and therapies to target mitochondrial dysfunction. In: Reeve AK, Simcox EM, Duchen MR, Turnbull DM, eds. Mitochondrial Dysfunction in Neurodegenerative Disorders. Springer $2^{\text {nd }}$ ed. Int Publishing 2016;349-371.

55. Moosmann B and Behl C. Antioxidants as treatment for neurodegenerative disorders. Expert Opin Invest Drugs. 2002;11:1407-35.

56. van Muiswinkel FL and Kuiperij HB. The Nrf2-ARE signalling pathway: promising drug target to combat oxidative stress in neurodegenerative disorders. Curr Drug Targets CNS Neurol Disord. 2005;4:267-81.

57. Nguyen T, Sherratt PJ, Pickett CB. Regulatory mechanisms controlling gene expression mediated by the antioxidant response element. Annu Rev Pharmacol Toxicol. 2003; 43:233-60.

58. Surh YJ, Kundu JK, Na HK. Nrf2 as a master redox switch in turning on the cellular signaling involved in the induction of cytoprotective genes by some chemopreventive 
phytochemicals. Planta Med. 2008;74:1526-39.

59. Wu KC, McDonald PR, Liu J, Klaassen CD. Screening of natural compounds as activators of the Keap 1-Nrf2 pathway. Planta Med. 2013;80:97-104.

60. Calkins MJ, Johnson DA, Townsend JA, Vargas MR, Dowell JA, Williamson TP, Kraft AD, Lee JM, Li J, Johnson JA. The Nrf2/ARE pathway as a potential therapeutic target in neurodegenerative disease. Antioxid Redox Signal. 2009;11:497-508.

61. Lee C, Park GH, Lee SR, Jang JH. Attenuation of betaamyloid-induced oxidative cell death by sulforaphane via activation of NF-E2-related factor 2. Oxid Med Cell Longev. 2013; $2013: 313510$.

62. Eggler AL, Gay KA, Mesecar AD. Molecular mechanisms of natural products in chemoprevention: induction of cytoprotective enzymes by Nrf2. Mol Nutr Food Res. 2008;52 (Suppl. 1):S84-S94.

63. Yang L, Zhao K, Calingasan NY, Luo G, Szeto HH, Beal MF. Mitochondria targeted peptides protect against 1-methyl-4-phenyl-1,2,3,6-tetrahydropyridine neurotoxicity. Antioxid Redox Signal. 2009;11:2095-2104.

64. Miclea A, Leussink VI, Hartung HP, Gold R, and Hoepner R. Safety and efficacy of dimethyl fumarate in multiple sclerosis: a multi-center observational study. J Neurol. 2016.

65. Ahuja M, Ammal Kaidery N, Yang L, Calingasan N, Smirnova N, Gaisin A, Gaisina IN, Gazaryan I, Hushpulian DM, Kaddour-Djebbar I, Bollag WB, Morgan JC, Ratan RR, Starkov AA, Beal MF, Thomas B. Distinct Nrf2 signaling mechanisms of fumaric acid esters and their role in neuroprotection against 1-methyl-4phenyl-1,2,3,6- tetrahydropyridine-induced experimental Parkinson's-like disease. J Neurosci. 2016;36:6332-51.

66. Wenz T. Regulation of mitochondrial biogenesis and PGC-1alpha under cellular stress. Mitochondrion. 2013;13(2):134-42.

67. Chen $\mathrm{H}$ and Chan DC. Mitochondrial dynamics in mammals. Curr Top Dev Biol. 2004; 59:119-44.

68. Mishra P, Carelli V, Manfredi G, Chan DC. Proteolytic cleavage of Opa 1 stimulates mitochondrial inner membrane fusion and couples fusion to oxidative phosphorylation. Cell Metab. 2014;19(4):630-41.

69. Mourier A. Mitochondrial dynamics and neurodegeneration. In: Reeve AK, Simcox EM, Duchen MR, Turnbull DM, eds. Mitochondrial Dysfunction in Neurodegenerative Disorders. Springer $2^{\text {nd }}$ ed. Int Publishing 2016;175-191.

70. Youle RJ, Narendra DP. Mechanisms of mitophagy. Nat Publ Gr. 2011;12(1):9-14.

71. Wang D, Wang J, Bonamy GM, Meeusen S, Brusch RG, Turk C, Yang P, Schultz PG. A small molecule promotes mitochondrial fusion in mammalian. Angew Chem. 2012;51:9302-5.

72. Yue W, Chen Z, Liu H, Yan C, Chen M, Feng D, Yan C, Wu H, Du L, Wang Y, Liu J, Huang X, Xia L, Liu L, Wang X, Jin H, Wang J, Song Z, Hao X, Chen Q. A small natural molecule promotes mitochondrial fusion through inhibition of the deubiquitinase USP30. Cell Res. 2014;
24(4) :482-96.

73. Rappold PM, Cui M, Grima JC, Fan RZ, de Mesy-Bentley KL, Chen L, Zhuang X, Bowers WJ, Tieu K. Drp1 inhibition attenuates neurotoxicity and dopamine release deficits in vivo. Nat Commun. 2014; 5:5244.

74. Taymans JM, Greggio E. LRRK 2 Kinase Inhibition as a Therapeutic Strategy for Parkinson's Disease. Where Do We Stand ? Curr Neuropharmacol. 2016;14(3):214-25.

75. Ventura-Clapier R, Garnier A, Veksler V.Transcriptional control of mitochondrial biogenesis: the central role of PGC-1alpha. Cardiovasc Res. 2008;79:208-17.

76. Mudò G, Mäkelä J, Di Liberto V, Tselykh TV, Olivieri M, Piepponen P, Eriksson O, Mälkiä A, Bonomo A, Kairisalo M, Aguirre JA, Korhonen L, Belluardo N, Lindholm D. Transgenic expression and activation of PGC-1 $\alpha$ protect dopaminergic neurons in the MPTP mouse model of Parkinson's disease. Cell Mol Life Sci. 2012; 69:1153-65.

77. Borra MT, Smith BC, Denu JM. Mechanism of human SIRT 1 activation by resveratrol. J Biol Chem. 2005;280(17):17187-95.

78. Hasegawa K, Yasuda T, Shiraishi C, Fujiwara K, Przedborski S, Mochizuki H, Yoshikawa K. Promotion of mitochondrial biogenesis by necdin protects neurons against mitochondrial insults. Nat Commun. 2016;7:10943.

79. Otten EG, Manni D, Korolchuk VI. Mitochondrial degradation, autophagy and neurodegenerative disease. In: Reeve AK, Simcox EM, Duchen MR, Turnbull DM, eds. Mitochondrial Dysfunction in Neurodegenerative Disorders. $2^{\text {nd }}$ ed. Springer Int Publishing 2016;255-278.

80. Corti O, Lesage S, Brice A. What genetics tells us about the causes and mechanisms of Parkinson's disease. Physiol Rev. 2011;91(4):1161-218.

81. Trempe JF and Fon EA. Structure and function of Parkin, PINK 1, and DJ-1, the three musketeers of neuroprotection. Front Neurol. 2013;4:38.

82. Palacino JJ, Sagi D, Goldberg MS, Krauss S, Motz C, Wacker M, Klose J, Shen J. Mitochondrial dysfunction and oxidative damage in parkin-deficient mice. J Biol Chem. 2004;279(18):18614-22.

83. Gandhi S, Wood-Kaczmar A, Yao Z, Plun-Favreau H, Deas E, Klupsch K, Downward J, Latchman DS, Tabrizi SJ, Wood NW, Duchen MR, Abramov AY. PINK 1 associated Parkinson's disease is caused by neuronal vulnerability to calcium-induced cell death. Mol cell. 2009;33(5):627-38.

84. Canet-Avilés RM, Wilson MA, Miller DW, Ahmad R, McLendon C, Bandyopadhyay S, Baptista MJ, Ringe D, Petsko GA, Cookson MR The Parkinson's disease protein DJ-1 is neuroprotective due to cysteine-sulfinic acid-driven mitochondrial localization. Proc Natl Acad Sci USA. 2004;101(24):9103-8.

85. Thomas KJ, McCoy MK, Blackinton J, Beilina A, van der Brug M, Sandebring A, Miller D, Maric D, CedazoMinguez A, Cookson MR. DJ-1 acts in parallel to the PINK 1/parkin pathway to control mitochondrial function and autophagy. Hum Mol Genet. 2011;20(1):40-50. 
86. Bian M, Liu J, Hong X, Yu M, Huang Y, Sheng Z, Fei J, Huang F. Overexpression of parkin ameliorates dopaminergic neurodegeneration induced by 1-methyl4-phenyl-1,2,3,6-tetrahydropyridine in mice. PLoS Biol. 2012;7(6):e39953.

87. Santos RX, Correia SC, Carvalho C, Cardoso S, Santos MS, Moreira PI. Mitophagy in neurodegeneration:an opportunity for therapy? Curr Drug Targets. 2011; 12(6):790-9.

88. Cheng Y, Ren X, Hait WN, Yang JM. Therapeutic targeting of autophagy in disease: biology and pharmacology. Pharmacol Rev. 2013;65(4):1162-97.

89. Hasson SA, Fogel AI, Wang C, MacArthur R, Guha R, Heman-Ackah S, Martin S, Youle RJ, Inglese J. Chemogenomic profiling of endogenous PARK2 expression using a genome-edited coincidence reporter. ACS Chem Biol. 2015;10:1188-97.

90. Chambers JW, Pachori A, Howard S, Ganno M, Hansen D Jr, Kamenecka T, Song X, Duckett D, Chen W, Ling YY, Cherry L, Cameron MD, Lin L, Ruiz CH, Lograsso P. Small molecule c-jun-N-terminal kinase inhibitors protect dopaminergic neurons in a model of Parkinson's disease. ACS Chem Neurosci. 2011;2(4):198-206.

91. Hertz NT, Berthet A, Sos ML, Thorn KS, Burlingame AL, Nakamura K, and Shokat KM. A neo-substrate that amplifies catalytic activity of Parkinson's-disease-related kinase PINK1. Cell. 2013;154:737-47.

92. Bingol B, Tea JS, Phu L, Reichelt M, Bakalarski CE, Song Q, Foreman O, Kirkpatrick DS \& Sheng M. The mitochondrial deubiquitinase USP30 opposes parkinmediated mitophagy. Nature. 2014;510:370-75.

93. Mankovska IM., Rosova KV, Gonchar OO, Nosar VI, Bratus LV, Drevitska TI, Karasevich NV, Karaban IM. Effect of Capicor on the Parkinson's disease pathogenic links. Fiziol Zh. 2018;64(1):16-24 [Ukraine].

94. Gardian G, Yang L, Cleren C, Calingasan NY, Klivenyi P, Beal MF. Neuroprotective effects of phenylbutyrate against MPTP neurotoxicity. Neuromolecular Med. 2004;5:235-241.

95. Inden M, Kitamura Y, Takeuchi H, Yanagida T, Takata K, Kobayashi Y, Taniguchi T, Yoshimoto K, Kaneko M, Okuma Y, Taira T, Ariga H, and Shimohama S. Neurodegeneration of mouse nigrostriatal dopaminergic system induced by repeated oral administration of rotenone is prevented by 4-phenylbutyrate, a chemical chaperone. J Neurochem. 2007;101:1491-1504.

96. Wilkins HM, Carl SM, Swerdlow RH. Cytoplasmic hybrid (cybrid) cell lines as a practical model for mitochondri- opathies. Redox Biol. 2014;2(1):619-31.

97. Cooper O, Seo H, Andrabi S, Guardia-laguarta C. Pharmacological rescue of mitochondrial deficis in iPSC-derived neural cells from patients with familial Parkinson's disease. Sci Transl Med. 2012;4(141):141-90.

98. Sanders LH, Laganière J, Cooper O, Mak SK, Vu BJ, Huang YA, Paschon DE, Vangipuram M, Sundararajan R, Urnov FD, Langston JW, Gregory PD, Zhang HS, Greenamyre JT, Isacson O, Schüle B. LRRK2 mutations cause mitochondrial DNA damage in iPSC-derived neural cells from Parkinson's disease patients: reversal by gene correction. Neurobiol Dis. 2014;62:381-6.

99. Tang FL, Liu W, Hu JX, Erion JR, Ye J, Mei L, Xiong WC. VPS35 deficiency or mutation causes dopaminergic neuronal loss by impairing mitochondrial fusion and function. Cell Rep. 2015;12:1631-43.

100. Dong J, Li S, Mo JL, Cai HB, Le WD. Nurr1-based therapies for Parkinson's disease. CNS Neurosci Ther. 2016;22:351-59.

101. Lotharius J, Dugan LL, O'Malley KL. Distinct mechanisms underlie neurotoxin-mediated cell death in cultured dopaminergic neurons. J Neurosci Res. 1999;19(4):1284-93.

102. Jin H, Chen WQ, Tang XW, Chiang LY, Yang CY, Schloss JV, Wu JY. Polyhydroxylated C60, fullerenols, as glutamate receptor antagonists and neuroprotective agents. J Neurosci Res. 2000;62:600-7.

103. Foley S, Crowley C, Smaihi M, Bonfils C, Erlanger BF, Seta P, Larroque C. Cellular localisation of a water-soluble fullerene derivative. Biochem Biophys Res Commun. 2002;294 (1) :116-19.

104. Cai X, Jia H, Liu Z, Hou B, Luo C, Feng Z, Li W, Liu J. Polyhydroxylated fullerene derivative $\mathrm{C} 60(\mathrm{OH}) 24$ prevents mitochondrial dysfunction and oxidative damage in an MPP+-induced cellular model of Parkinson's disease. J Neurosci Res. 2008;86(16): 3622-34.

105. Prylutskyy YI, Vereshchaka IV, Maznychenko AV, Bulgakova NV, Gonchar OO, Kyzyma OA, Ritter U, Scharff P, Tomiak T, Nozdrenko DM, Mishchenko IV, Kostyukov AI. C60 fullerene as promising therapeutic agent for correcting and preventing skeletal muscle fatigue. J Nanobiotechnol. 2017; 15:8.

106. Gonchar O., Maznychenko A., Bulgakova N., Vereschaka I., Tomiak T., Ritter U., Prylutskyy Y., Mankovska I., Kostyukov A. C60 Fullerene prevents restraint stressinduced oxidative disorders in rat tissues: possible involvement of the Nrf2/ARE-antioxidant pathway. Oxid Med Cell Long. 2018; 2018 (Article ID 2518676): 17. 